\section{Case Reports in Gastroenterology}

Case Rep Gastroenterol 2017;11:1-8

DOI: $10.1159 / 000454711$

Publisned onimne: January 27, 2017
(C) 2017 The Author(s)

Published by S. Karger AG, Basel

www.karger.com/crg

This article is licensed under the Creative Commons Attribution-NonCommercial 4.0 International License (CC BY-NC) (http://www.karger.com/Services/OpenAccessLicense). Usage and distribution for commercial purposes requires written permission.

\title{
Brunner's Gland Adenoma - A Rare Cause of Gastrointestinal Bleeding: Case Report and Systematic Review
}

\author{
Michele Sorleto Annette Timmer-Stranghöner Helge Wuttig \\ Oliver Engelhard Carsten Gartung \\ Division of Gastroenterology and Hepatology, Department of Internal Medicine, \\ University Hospital Johannes-Wesling-Klinikum Minden, Minden, Germany
}

\section{Keywords}

Brunner's gland adenoma - Gastrointestinal bleeding · Small bowel neoplasm - Endoscopic removal

\begin{abstract}
Brunner's gland adenoma is an extremely rare benign small bowel neoplasm, often discovered incidentally during upper gastrointestinal endoscopy or radiological diagnostics. In few cases, it tends to cause gastrointestinal hemorrhage or intestinal obstruction. We report here our experience with a 47-year-old woman with a Brunner's gland adenoma of more than $6 \mathrm{~cm}$ in size, located in the first part of the duodenum and causing gastrointestinal bleeding. Initially, we performed a partial endoscopic resection using endoloop and snare alternatively to prevent severe bleeding. A rest endoscopic polypectomy with the submucosal dissection technique was planned. However, on request of the patient, an elective surgical duodenotomy with submucosal resection of the remaining small duodenal tumor was performed. To better define the patient's characteristics and treatment options of such lesions, we performed a systematic review of the available literature in PubMed. Recently, an endoscopic
\end{abstract}




\section{Case Reports in Gastroenterology}

Case Rep Gastroenterol 2017;11:1-8

(c) 2017 The Author(s). Published by S. Karger AG, Basel www.karger.com/crg

Sorleto et al: Brunner's Gland Adenoma - A Rare Cause of Gastrointestinal Bleeding: Case Report and Systematic Review

removal is being increasingly practiced and is considered as a safe treatment modality of such lesions.

(C) 2017 The Author(s)

Published by S. Karger AG, Basel

\section{Introduction}

Primary duodenal tumors are rare, accounting for less than $1 \%$ among all gastrointestinal tumors $[1,2]$. Brunner's gland adenoma, also known as Brunner's hamartoma is a rare benign small bowel neoplasm with an estimated incidence of less than $0.01 \%$ [3]. Curveilhier described the first case of benign duodenal Brunner's gland adenoma in 1835 [4]. The pathogenesis of this rare tumor of the duodenum is still unknown. Generally, it is an incidental finding discovered in an upper gastrointestinal endoscopy (EGD) and presenting as a single pedunculated polyp, with an average size of $2 \mathrm{~cm}$. Occasionally, they may be larger than $5 \mathrm{~cm}$, and located in the first section of the duodenum [5]. Most duodenal tumors of Brunner's glands are demonstrated as hyperplastic or hamartomatous mucosal changes and their malignant transformation has been reported to be extremely rare [6, 7]. In a recent study, dysplastic changes were seen in $2.1 \%$ and invasive carcinoma in $0.3 \%$ of all Brunner's gland hyperplasia [8]. Most patients are asymptomatic, although they can present with common gastrointestinal symptoms like bleeding, nausea, vomiting, or chronic abdominal pain. We present an illustrative case of a female patient with a duodenal polypoid mass of more than $6 \mathrm{~cm}$ who was admitted to our department with upper gastrointestinal bleeding. Furthermore, a systematic review of the available literature was conducted.

\section{Case Report}

A 47-year-old woman arrived at our emergency room with melena and anemia accompanied by epigastric pain. She had not taken any medication including nonsteroidal antiinflammatory drugs. She also had no specific family or past medical history. Physical examination on admission revealed normal vital signs; she was afebrile with a soft and nontender abdomen. However, melena was detected in the rectal examination and the laboratory data showed a hemoglobin concentration of $8.2 \mathrm{~g} / \mathrm{dL}$ (normal range: 12.0-16.0), and mean corpuscular volume of $88 \mathrm{fl}$ (normal range: 80-96). The emergency EGD revealed a large pedunculated polyp $(3 \times 6 \mathrm{~cm})$ in the first section of the duodenum with stigmata of recent hemorrhage which almost occluded the duodenal lumen completely (Fig. 1). The patient was transferred to our intensive care unit and was administered pantoprazole intravenously at $10 \mathrm{mg} / \mathrm{h}$ after an 80-mg loading dose. Contrast-enhanced computed tomography scan showed a heterogeneously enhancing intraluminal mass arising from the proximal duodenum. Repeated upper endoscopy, performed 1 day later, revealed a not actively bleeding polyp located in the bulb of the duodenum. Because of the enormous size of the polyp, with a benign appearance, we decided to perform endoscopic resection. According to the high risk of bleeding an "endoloop" was placed around the base of the polyp. Then, resection was performed with a $30-\mathrm{mm}$ standard snare. This procedure was repeated 3 times until the bulk seemed to be removed (Fig. 2, Fig. 3). The endoscopic view was quiet poor because the base 


\section{Case Reports in \\ Gastroenterology}

Case Rep Gastroenterol 2017;11:1-8

DOI: $10.1159 / 00045471$

(9)

C) 2017 The Author(s). Published by S. Karger AG, Base www.karger.com/crg

Sorleto et al: Brunner's Gland Adenoma - A Rare Cause of Gastrointestinal Bleeding: Case Report and Systematic Review

was placed directly behind the pylorus. To avoid perforation, the intervention was stopped at the moment, and endoscopic ultrasound (EUS) was performed the next day. The Brunner's gland hyperproliferation was extended within the submucosa with a distance of 1-2 $\mathrm{mm}$ to the muscularis (Fig. 4), though the endoscopic examination showed a strong vascularity of the submucosal lesions. Evaluating the findings of endoscopy, EUS and computed tomography scan we discussed either endoscopic mucosal resection (EMR), endoscopic submucosal dissection (ESD), or surgical management. After discussions of all approaches with the patient, including the risk of endoscopic perforation or bleeding, the patient consented to an elective duodenotomy. Following the preoperative checkup, exploratory laparotomy was done. The duodenum was mobilized with a Kocher maneuver. The pylorus was identified and a longitudinal incision was made on the pylorus ring for duodenal mucosa exploration. During the exploration, the mass was removed from the base and sent for histopathological examination. Histologically, there was no evidence of malignancy, and once again, it was confirmed as a Brunner's gland adenoma measuring $16 \times 15 \times 6 \mathrm{~mm}$ with a residual peduncle of $4 \mathrm{~mm}$. No necrosis or cystic changes were seen. Microscopy showed a polypoid tumor covered by small intestinal mucosa. The tumor was composed of lobules of Brunner's glands with a few dilated glands. There was no evidence of dysplasia or malignancy. Finally, the patient was subsequently discharged without any complications and in good health.

\section{Discussion and Conclusions}

Usually, polyps arise from the mucosal layer although some submucosal pathologies may cause mucosal protrusion into the lumen and resemble mucosal polyps. Brunner glands are branched acinotubular glands with submucosal location found exclusively between the pyloric ring and the papilla of Vater. They secrete an alkaline fluid composed of viscous mucin to protect the duodenal epithelium from acid chyme of the stomach. Brunner's gland adenoma is a rare tumor-like lesion, mostly present in middle age without sex predominance [9]. Curveilhier described the first case of benign duodenal Brunner's gland adenoma in 1835 [4]. In 1688, Brunner gave a precise anatomic description of the duodenal submucosal glands and coined the term "pancreas secundarium". In 1846, Middeldorpf corrected these glands' name as Brunner's glands. Presently, fewer than 200 cases have been described with synonyms of Brunner gland adenoma, Brunner gland hamartoma, or Brunneroma [10]. Brunner gland adenoma is generally a single pedunculated polyp, with an average size of $2 \mathrm{~cm}$, rarely larger than $5 \mathrm{~cm}$, and located in the first section of the duodenum. Nonetheless, primary duodenal tumors are rare, accounting for less than $1 \%$ among the total gastrointestinal tumors even though they rarely have a malignant transformation $[5,6]$. In a recent study, dysplastic changes were seen in $2.1 \%$ and invasive carcinoma in $0.3 \%$ of all Brunner's gland hyperplasia [7]. The precise pathogenesis is poorly understood but the excessive local irritation from acidic gastric chyme, vagal stimuli, or unidentified antral hormones seems to have relevance [11]. Helicobacter pylori infection is accused of contributing to the pathogenesis of Brunner's gland hamartoma. In a study, 5 of 7 cases had concurrent $H$. pylori infection. Also in our case, the patient had a histopathological evidence of H. pylori. Nevertheless, the definite relationship has not yet been proven because of the high prevalence of $H$. pylori and the rarity of this lesion in the general population [12]. Some authors have further divided 


\section{Case Reports in \\ Gastroenterology}

Case Rep Gastroenterol 2017;11:1-8

DOI: $10.1159 / 00045471$

(c)

(C) 2017 The Author(s). Published by S. Karger AG, Basel www.karger.com/crg

Sorleto et al.: Brunner's Gland Adenoma - A Rare Cause of Gastrointestinal Bleeding: Case Report and Systematic Review

these lesions as follows: for lesions of less than $1 \mathrm{~cm}$, the term "hyperplasia" is used while the term "adenoma" has been used for lesions of more than $1 \mathrm{~cm}$ and the term "hamartoma" if it also contains mesenchymal elements. Brunner's gland adenoma is usually asymptomatic and detected incidentally. More frequently, patients have vague upper gastrointestinal symptoms. Clinical presentations may include obstructive symptoms, pancreatitis, and upper gastrointestinal bleeding. Useful diagnostic tools are barium contrast studies, abdominal $\mathrm{CT}$, and endoscopy. Further large adenomas may be detected by ultrasonography. The main differential diagnoses are gastrointestinal stromal tumor, lymphoma, carcinoid, PeutzJeghers polyps, prolapsed pyloric mucosa, or aberrant pancreatic tissue. After histopathological examination, treatment is recommended for tumors larger than $2.0 \mathrm{~cm}$, even if they are asymptomatic. Although endoscopic techniques of removal are more helpful, this procedure can be limited by difficult anatomical sites, so that various strategies, such as endoscopic, surgical, or a combination of both, are used, depending on the situation $[3,13]$. Presently, there is no relevant data of recurrence in such a lesion as well as any guidance in the followup. Initially, we performed a partial endoscopic resection using endoloop and snare alternatively to prevent severe bleeding. A rest endoscopic polypectomy with the submucosal dissection technique was planned. However, on request of the patient, an elective surgical duodenotomy with submucosal resection of the remaining small duodenal tumor was performed. To better define the patient's characteristics and treatment options of these lesions, a systematic review of the available literature in PubMed was performed (Table 1). Nowadays, an endoscopic removal of such lesions has commonly increased, and became a safe treatment modality utilizing advanced endoscopic equipment, particularly for benign submucosal tumors. Various endoscopic procedures, including snare resection, ESD, and the endoloop technique have been introduced for safe resection of benign tumors. Duodenal lesions susceptible to endoscopic resection include premalignant lesions like adenomas, benign lesions (Brunner hyperplasia or lipoma), and submucosal lesions with malignant potential like neuroendocrine tumors (NET) or gastrointestinal stromal tumors (GIST) (Table 2) $[14,15]$. ESD can be safe if performed while continuously observing the dissected layer. Furthermore, submucosal dissection in coagulation mode is used to control the depth of the cut and reduce the risk of bleeding. Due to high complication rates (bleeding, perforation), duodenal ESD must be performed by highly experienced ESD endoscopists. In conclusion, ESD could be a safe modality of treatment and less invasive in our case.

\section{Statement of Ethics}

There are no ethical conflicts to declare. Informed consent has also been obtained from the involved patient, and there is no identifying patient information in the manuscript.

\section{Disclosure Statement}

The authors certify that they have no affiliations with or involvement in any organization or entity with any financial interest (such as honoraria; educational grants; participation in speakers' bureaus; membership, employment, consultancies, stock ownership, or other 
Sorleto et al.: Brunner's Gland Adenoma - A Rare Cause of Gastrointestinal Bleeding: Case Report and Systematic Review

equity interest; and expert testimony or patient-licensing arrangements), or non-financial interest (such as personal or professional relationships, affiliations, knowledge or beliefs) in the subject matter or materials discussed in the manuscript.

\section{References}

1 Van de Walle P, Dillemans B, Vandelanotte M, Proot L: The laparoscopic resection of a benign stromal tumour of the duodenum. Acta Chir Belg 1997;97:127-129.

-2 Ohba R, Otaka M, Jin M, Odashima M, Matsuhashi T, Horikawa Y, Hatakeyama N, Mimori N, Kinoshita N, Koizumi S, Takahashi T, Watanabe S: Large Brunner's gland hyperplasia treated with modified endoscopic submucosal dissection. Dig Dis Sci 2007;52:170-172.

-3 Stewart ZA, Hruban RH, Fishman EF, Wolfgang CL: Surgical management of giant Brunner's gland hamartoma: case report and literature review. World J Surg Oncol 2009; 7:68.

4 Cruveilhier J: Anatomy of the Human Body. New York, Harper and Bros, 1844.

5 Jung Y, Chung IK, Lee TH, Cho YS, Jo YG, Park SH, Cho H, Kim SJ: Successful endoscopic resection of large pedunculated Brunner's gland hamartoma causing gastrointestinal bleeding arising from the pylorus. Case Rep Gastroenterol 2013;7:304-307.

6 Brookes MJ, Manjunatha S, Allen CA, Cox M: Malignant potential in a Brunner's gland hamartoma. Postgrad Med J 2003;79:416-417.

7 Faller G, Kirchner T: Low grade intraepithelial neoplasia of Brunner's gland. Histopathology 2005;47:118-119.

-8 Sakurai T, Sakashita H, Honjo G, Kasyu I, Manabe T: Gastric foveolar metaplasia with dysplastic changes in Brunner gland hyperplasia. Am J Surg Pathol 2005;29:1442-1448.

-9 Levine JA, Burgart LJ, Kbatts KP, Wang KK: Brunner's gland hamartomas: clinical presentation and pathological features of 27 cases. Am J Gastroent 1995;90:290-294.

10 Peison B, Benisch B: Brunner's gland adenoma of the duodenal bulb. Am J Gastroenterol 1982;77:276278.

11 Stolte M, Schwabe H, Prestele H: Relationship between diseases of the pancreas and hyperplasia of Brunner glands. Virchows Arch A Pathol Anat Histol 1981;394:75-87.

-12 Yadav D, Hertan H, Pitchumoni CS: A giant Brunner's gland adenoma presenting as gastrointestinal hemorrhage. J Clin Gastroenterol 2001;32:448-450.

-13 De la Riva S, Carrascosa J, Munoz-Navas M, Súbtil JC, Carretero C, Sola JJ, Hernández-Lizoain JL: Giant Brunner's gland hamartoma: diagnosis and endoscopic treatment. Gastroenterol Hepatol 2011;34:333336.

14 Bourke MJ: Endoscopic resection in the duodenum: current limitations and future directions. Endoscopy 2013;45:127-132.

$\checkmark 15$ Gaspar JP, Stelow EB, Wang AY: Approach to the endoscopic resection of duodenal lesions. World J Gastroenterol 2016;22:600-617. 
Sorleto et al.: Brunner's Gland Adenoma - A Rare Cause of Gastrointestinal Bleeding: Case Report and Systematic Review

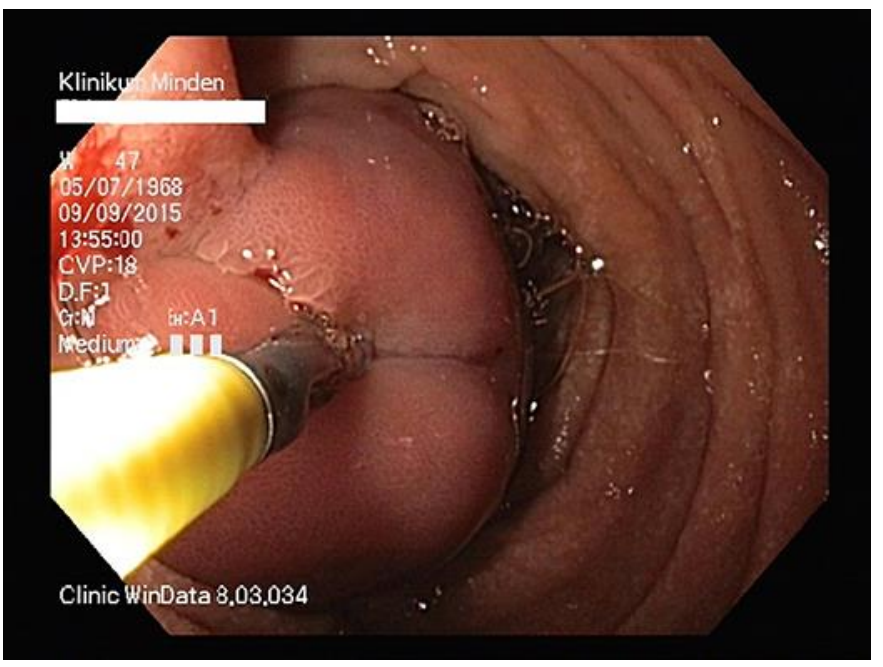

Fig. 1. Large pedunculated polyp $(3 \times 6 \mathrm{~cm})$ in the first section of the duodenum with stigmata of recent hemorrhage which almost occluded the duodenal lumen completely.

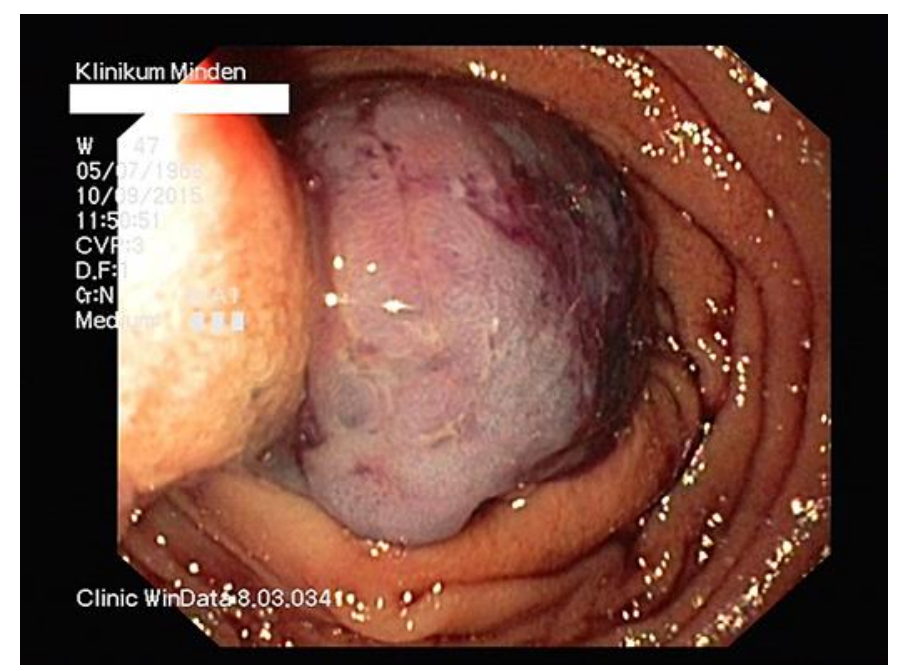

Fig. 2. Endoscopic resection with a 30-mm standard snare. 


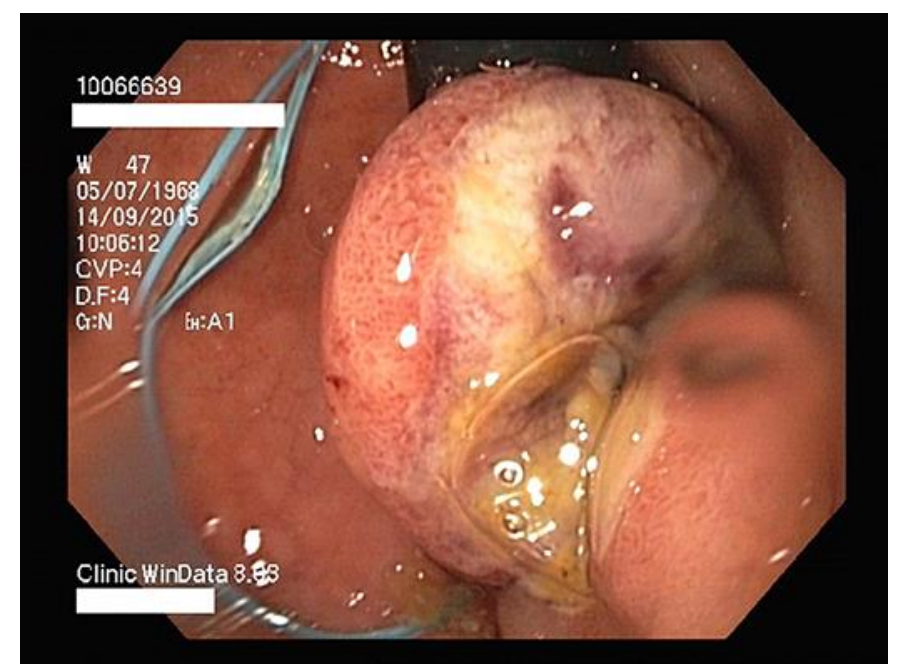

Fig. 3. Endoscopic resection.

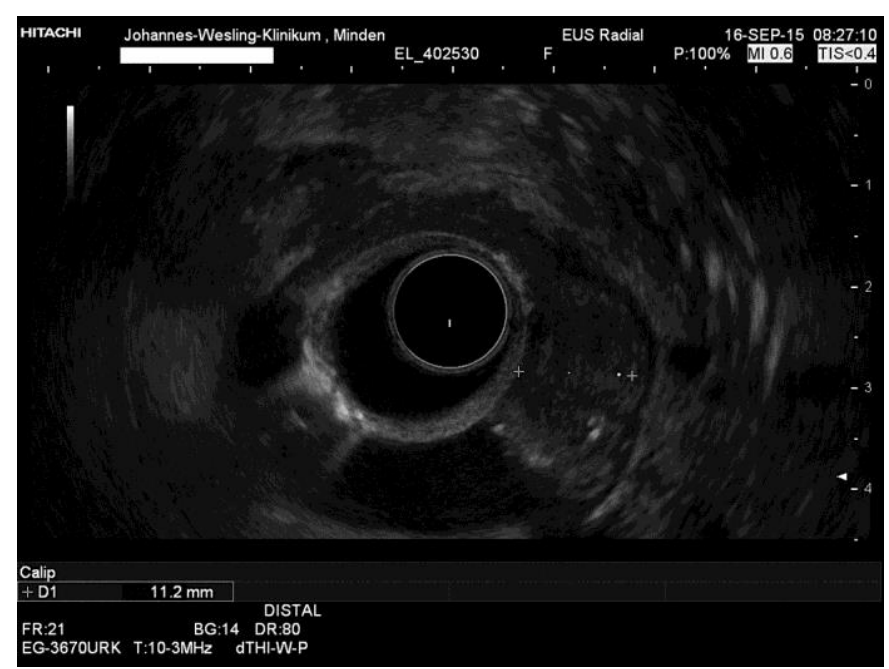

Fig. 4. The Brunner's gland hyperproliferation was extended within the submucosa with a distance of 1-2 $\mathrm{mm}$ to the muscularis. 


\section{Case Reports in Gastroenterology}

Table 1. Summary of previously reported reviews of the literature of Brunner's gland hamartomas

\begin{tabular}{|c|c|c|}
\hline First author & Article & References \\
\hline Salvioli G. & Contribuzione allo studio degli adenomi & $\begin{array}{l}\text { L'Osservatore e Gazzetta } \\
\text { Medica di } \\
\text { Torino 1876;12:481 }\end{array}$ \\
\hline Oliver et al. & $\begin{array}{l}\text { Giant hamartoma of Brunner's glands: apropos of a case and review of the } \\
\text { literature }\end{array}$ & $\begin{array}{l}\text { Esp Enferm Apar Dig } \\
1987 ; 72: 365-367\end{array}$ \\
\hline De Angelis et al. & $\begin{array}{l}\text { Hamartomatous polyps of Brunner's gland. Presentation of } 2 \text { cases. Review } \\
\text { of the literature }\end{array}$ & $\begin{array}{l}\text { Minerva Chir } \\
1989 ; 44: 1761-1766 .\end{array}$ \\
\hline Walden et al. & $\begin{array}{l}\text { Endoscopic injection and polypectomy for bleeding Brunner's gland } \\
\text { hamartoma: case report and expanded literature review }\end{array}$ & $\begin{array}{l}\text { Gastrointest Endosc } \\
1998 ; 47: 403-407\end{array}$ \\
\hline Stolpman et al. & $\begin{array}{l}\text { Brunner's gland hamartoma: a rare cause of gastrointestinal bleeding: a case } \\
\text { report and review of the literature }\end{array}$ & $\begin{array}{l}\text { Can J Gastroenterol } \\
2002 ; 16: 309-313\end{array}$ \\
\hline Gao et al. & Brunner's gland adenoma of duodenum: a case report and literature review & $\begin{array}{l}\text { World J Gastroenterol } \\
2004 ; 10: 2616-2617\end{array}$ \\
\hline Rocco et al. & Large Brunner's gland adenoma: case report and literature review & $\begin{array}{l}\text { World J Gastroenterol } \\
2006 ; 12: 1966-1968\end{array}$ \\
\hline Sammarco et al. & Brunner's gland hamartoma: a case report and review of literature & $\begin{array}{l}\text { Ann Ital Chir } \\
2008 ; 79: 139-142\end{array}$ \\
\hline Stewart et al. & $\begin{array}{l}\text { Surgical management of giant Brunner's gland hamartoma: case report and } \\
\text { literature review }\end{array}$ & $\begin{array}{l}\text { World J Surg Oncol } \\
2009 ; 7: 68\end{array}$ \\
\hline Euanorasetr et al. & $\begin{array}{l}\text { Surgical management of Brunner's gland hamartoma causing upper GI hem- } \\
\text { orrhage: report of two cases and literature review }\end{array}$ & $\begin{array}{l}\text { J Med Assoc Thai } \\
2010 ; 93: 1232-1237\end{array}$ \\
\hline
\end{tabular}

Table 2. Endoscopic procedures for the potential resection of elevated or sessile mucosally based duodenal lesions (typically for duodenal adenomas)

\begin{tabular}{|c|c|c|c|c|}
\hline Type of duodenal lesion & $\begin{array}{l}\text { Duodenal } \\
\text { wall layer }\end{array}$ & $\begin{array}{l}\text { Malignant } \\
\text { potential }\end{array}$ & $\begin{array}{l}\text { Requires } \\
\text { resection }\end{array}$ & $\begin{array}{l}\text { Amenable to endoscopic re- } \\
\text { section }\end{array}$ \\
\hline Lipoma & subepithelial & no & no & possible \\
\hline Gastrointestinal stromal tumors & subepithelial & yes & yes & possible (for small lesions) \\
\hline Carcinoids $\rightarrow$ subepithelial & yes & yes & $\begin{array}{l}\text { possible (for rare, } \\
\text { isolated lesions) }\end{array}$ & often requires surgery \\
\hline $\begin{array}{l}\text { Brunner's gland "adenomas" or } \\
\text { hamartomas }\end{array}$ & mucosal & no & $\begin{array}{l}\text { if patients are } \\
\text { symptomatic }\end{array}$ & yes \\
\hline Solitary Peutz-Jeghers polyps & mucosal & yes & yes & yes \\
\hline Adenoma & mucosal & yes & yes & yes \\
\hline
\end{tabular}

